\title{
Internal and External Causes of the Recent Climatic Change:
}

\author{
A Numerical Study with an Energy Balance Model
}

\author{
By Hiroyoshi Hatazawa ${ }^{1}$ and Tatsuya Iwashima \\ Laboratory for Climatic Change Research, Faculty of Science, Kyoto University \\ 17-1, Ohmine-cho, Kitakazan, Yamashina-ku, Kyoto 607, Japan \\ (Manuscript received 25 April 1989, in revised form 12 April 1990)
}

\begin{abstract}
By using a simple energy balance climate model and observed surface air temperature data, we investigate several internal and external causes of the globally or hemispherically averaged recent climatic change. Among the external causes, the increase of atmospheric $\mathrm{CO}_{2}$ concentration brings a warming trend of the surface air temperature, which may be detected in the next thirty years with a statistical confidence limit of more than $78 \%$; the volcanic activity is responsible for the decade-todecade temperature change and the effect of the anthropogenic aerosols may have contributed to the recent temperature changes. Also, we examine the effects of multiplicative and additive stochastic forcings as internal causes. Although Nicolis (1988) noted the increase of the temperature variance by the multiplicative stochastic forcing, we could not find such a monotonic increase in the variance of the temperature observed in the last hundred years. The additive stochastic forcing may contribute to a year-to-year temperature variation, and its magnitude corresponds to $0.22-0.28 \%$ of the input of the solar radiation at the top of the atmosphere.
\end{abstract}

\section{Introduction}

The climate of the earth changes virtually on all time scales greater than about a year. Although climatic variations back to thousands of years have been deduced by using ice cores from Greenland or Antarctica, only very few data of the meteorological elements directly observed are available except for limited stations back to the 17th century. Hemispherical or global mean of surface air temperature is estimated for only the last hundred years from the observed data, even though several problems still remain in evaluating the global or hemispherical mean temperature from spatially limited data (Yamamoto and Hoshiai, 1980: Jones et al., 1986a, b; Hansen and Lebedeff, 1987, 1988).

There are several studies about causes of the temperature variation in the recent hundred years (Miles and Gildersleeves, 1978: Madden and Ramanathan, 1980). Madden and Ramanathan noted, based on the data of surface air temperature at $60^{\circ} \mathrm{N}$, that the effect of the $\mathrm{CO}_{2}$ increase might be detectable, but that the data analysis did not reveal such changes for the following two reasons : there are the other factors that compensate for the warming due to the $\mathrm{CO}_{2}$ effect; and/or the warming is

\footnotetext{
${ }^{1}$ Present Affiliation: Fujitsu Social Science Laboratory, Ltd., 1-chome, 6-4, Oosaki, Shinagawa-ku, Tokyo 141, Japan (C)1990, Meteorological Society of Japan
}

delayed because of the thermal inertia of the ocean.

Several researchers simulated the recent change of the globally or hemispherically averaged temperature by using simple climate models (Robock, 1978: Hansen et al. 1981; Gilliland, 1982): Using a 1-dimensional radiative-convective model with $\mathrm{CO}_{2}$, volcanic and solar activity forcing, Hansen et al. (1981) concluded that the $\mathrm{CO}_{2}$ and volcanic effects are responsible for much of the global temperature variation in the past century. On the other hand, using a globally averaged two-box (surface layer and deep ocean) energy balance model with the same three external forcings, Gilliland (1982) asserted that solar activity, especially of a 76-year cycle, has an important effect. However, they did not make clear the relative magnitudes of the external forcings to the recent climatic change and did not discuss the internal causes.

Viewing with the time scale of more than a year, we can regard daily weather as random fluctuations: it may have an effect on a larger spatial and temporal scale field as a stochastic forcing. In this work we will consider the stochastic forcing as an internal cause.

Robock (1978) concluded that climatic changes can be forced only by the random fluctuations of the atmospheric meridional heat transport by the small scale eddies, even though it is also shown in his study 
that volcanic dust has been an important cause of climatic change. In fact he estimated the effects of internal and external forcings separately, but did not draw conclusions on their relative magnitude to the climatic variation.

Nicolis (1988) considered four types of stochastic process: Gaussian white and red noise, and additive and multiplicative processes for each noise type. White noise has no characteristic time scale, while red noise has a certain time scale. The additive process has a one-way effect and no feedbacks, but the multiplicative one has a feedback effect from the main field. Concerning these stochastic processes Nicolis (1988) did not conclude what type of noise process could effectively work as stochastic forcing in the real atmosphere, except for the following:

(1) An increase in the variance of temperature is expected for a multiplicative noise process if there is a systematic increase in the $\mathrm{CO}_{2}$ concentration. This kind of increase is seen also in the observed data of Angell and Korshover (1977).

(2) In the case of additive white noise, the time evolution of the computed temperature is similar to that of the observed data, where it has an increasing stage followed by a slowing down or a plateau.

(3) In the case of additive red noise, the time evolution is closer to the observed data with respect to the long-lived fluctuations and its smoothness.

In the present work, we will try to answer the above-mentioned question about the forcing factors in the climatic change during the recent hundred years by numerical experiments with an energy balance model.

We will closely examine the external $\left(\mathrm{CO}_{2}\right.$ effect, volcanic effect and solar activity etc.) and internal (a stochastic forcing) causes in the recent climatic change. In the present work we will not discuss the internal causes in detail.

The models and equations used in the present work are described in Section 2. In Section 3, we present our results with comments on the conclusion of Nicolis (1988), with respect to the above causes. In Section 4, we discuss the magnitude of the stochastic forcing and the "detectability" of the temperature increase due to $\mathrm{CO}_{2}$-caused greenhouse effect. Finally Section 5 gives conclusions.

\section{Models and observed temperature data}

In this section, we briefly describe the model of Nicolis (1988), our modified model, and the time series of observed temperature data for later comparison.

\subsection{Nicolis model (Model I)}

Nicolis used a linearized energy balance equation as follows:

$$
\frac{d x}{d t}=-\lambda x+\frac{K}{C} \varepsilon t+\frac{1}{C} g(x) F(t)
$$

were $x=T-T_{0}$ ( $T$ : the globally averaged temperature, $T_{0}$ : the temperature of a reference state corresponding, for instance, to pre-industrial conditions), $\lambda$ the inverse relaxation time, $C$ the heat capacity of the system, and $\varepsilon$ the rate of $\mathrm{CO}_{2}$ increase. Three terms on the right-hand side represent infrared cooling effect, $\mathrm{CO}_{2}$ heating effect, and stochastic forcing, respectively. The formulation of the second term is based on the result of radiative convective models (Augustsson and $\mathrm{Ra}$ manathan, 1977), according to which a systematic $\mathrm{CO}_{2}$ increase will show up as an additive contribution of the form $K \cdot \ln \left(c / c_{0}\right)$ (c: the $\mathrm{CO}_{2}$ concentration, $c_{0}$ : its value at the reference state, $K$ : a constant), and exponential change of $c / c_{0}$ is supposed. In the third term, $F(t)$ represents a noise process (Gaussian white noise or red noise), and $g(x)$ the coupling between the dynamics and the fluctuations (additive fluctuations, $g=1$ or multiplicative ones, $g=-\lambda x)$. The values of the coefficients shown in Table 1 are used.

Table 1. Values of constants used in the Nicolis (1988) model.

\begin{tabular}{r||l}
\hline$\lambda$ & 0.25 year $^{-1}$ \\
$\mathrm{~K}$ & 0.68 \\
$\mathrm{C}$ & $4.0 \mathrm{~W} \cdot \mathrm{yr} / \mathrm{m}^{2} / \mathrm{K}$ \\
$\varepsilon$ & 0.01 \\
\hline
\end{tabular}

The rate of the $\mathrm{CO}_{2}$ increase used in the Nicolis model seems inappropriate. When we assume the pre-industrial $\mathrm{CO}_{2}$ concentration $\left(c_{0}\right)$ to be 270 ppmv, the value $\varepsilon=0.01$ gives the evolution of $\mathrm{CO}_{2}$ concentration like curve (b) in Fig. 1. The rate of the increase, which is assumed in the form $c=$ $c_{0} \cdot \exp (\varepsilon t)$, is too fast. When we use the above form to simulate the $\mathrm{CO}_{2}$ increase, the value of $\varepsilon$ must be reduced rather (see curve (c) in Fig. 1): The temperature change depends on the coefficient $\varepsilon$, and the temperature slowly increases in the case of small $\varepsilon$. Then the value of $K$ must be increased to simulate the temperature trend observed in the record. But it is obvious that another formulation, for instance, $c=c_{0}+c_{1} \cdot \exp (\varepsilon t)$ as was given by Hoffert and Flannery (1985), can simulate this trend more suitably as in curve (a). We will adapt this formulation to Nicolis model and modify it.

Here we note that, in Eq. (1), the solar radiation term disappeared through the linearization process. However, taking account of the fluctuation of the term, we should explicitly add it to Eq. (1).

\subsection{The modified model (Model II)}

In order to compare the model results with the observed temperature data, we modify Nicolis (1988) model (Model I) more suitably in the following main points. 


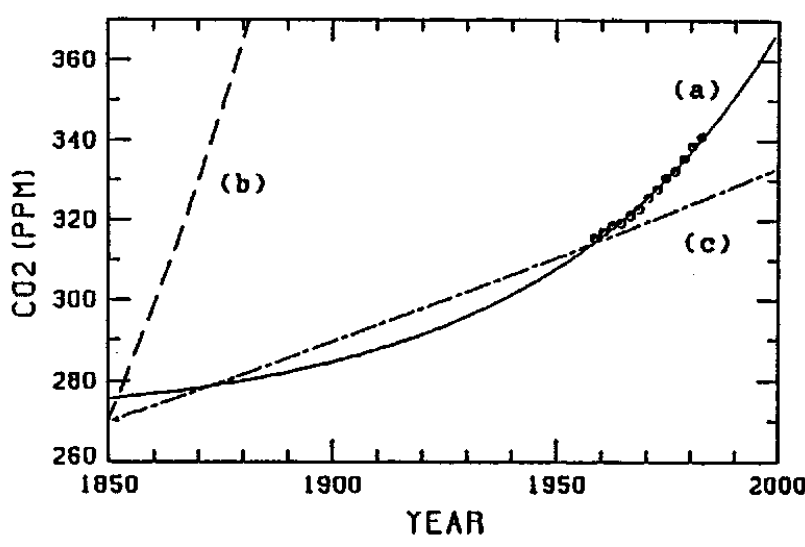

Fig. 1. Estimates of the $\mathrm{CO}_{2}$ increase by three formulae: curve (a): $c=270+$ $44 \exp \{0.019(t-1958)\}$, after Hoffer and Flannery (1985); curve (b): $c=270$ $\exp \{0.01(t-1850)\}$, after Nicolis $(1988)$; curve (c): $c=270 \exp \{0.0014(t-1850)\}$, where $c$ is $\mathrm{CO}_{2}$ concentration and $\mathrm{t}$ is year in A.D. Small circles denote observed values.

(1) We include the effects of volcanic activity and, in some cases, the direct solar radiation variation.

(2) In order to model the $\mathrm{CO}_{2}$ increase, we adopt the formulation of Hoffert and Flannery (1985) as was commented above.

(3) We use three different values as the heat capacity of the system, i.e., that of the Northern Hemisphere $\left(C_{N}\right)$, the Southern Hemisphere $\left(C_{S}\right)$, and the entire globe $\left(C_{G}\right)$.

(4) The inverse relaxation time ( $\lambda$ in Nicolis model) is in the other form $B / C$ ( $B$ : a constant), by taking account of the dependence on the heat capacity.

The modified model equation is:

(i) in the case taking the $\mathrm{CO}_{2}$ effect only,

$$
\begin{aligned}
\frac{d x}{d t}=-\frac{B}{C} x+\frac{1}{C} F_{\mathrm{CO}_{2}} & \cdot K \ln \frac{c(t)}{c_{0}} \\
& \left(+\frac{1}{C} g(x) F(t)\right),
\end{aligned}
$$

(ii) in the case taking the effects of $\mathrm{CO}_{2}$ and volcanic activity,

$$
\begin{aligned}
\frac{d x}{d t} & =-\frac{B}{C} x+\frac{1}{C} F_{\mathrm{CO}_{2}} \cdot K \ln \frac{c(t)}{c_{0}} \\
& +\frac{1}{C} F_{\mathrm{VOL}} \cdot \operatorname{VOL}(t)\left(+\frac{1}{C} g(x) F(t)\right),
\end{aligned}
$$

(iii) in the case taking the effects of $\mathrm{CO}_{2}$ and solar radiation,

$$
\begin{aligned}
\frac{d x}{d t} & =-\frac{B}{C} x+\frac{1}{C} F_{\mathrm{CO}_{2}} \cdot K \ln \frac{c(t)}{c_{0}} \\
& +\frac{1}{C} F_{\mathrm{RAD}} \cdot \operatorname{RAD}(t)\left(+\frac{1}{C} g(x) F(t)\right),
\end{aligned}
$$

where

$$
\begin{aligned}
x & =T-T_{0} \text { (same as Nicolis), } \\
c(t) & =270+44 \cdot \exp \{0.019(t-1958)\}, \\
& t \text { in year (A.D.), } \\
c_{0} & =c(1870), \\
C & =C_{N}, C_{S}, \text { or } C_{G} .
\end{aligned}
$$

Following Harvey and Schneider (1985a, b), we assume that the depth of ocean mixed layer is a hundred meters, and that the heat capacity of land is equivalent to $1.7 \mathrm{~m}$ of water. $C_{N}, C_{S}$, and $C_{G}$ are hemispherical and global area-weighted means of ocean and land heat capacity. The coefficients in the model equation are listed in Table 2.

Table 2. Values of constants used in the modified model. Values of $\mathrm{B}$ and $\mathrm{K}$ are adopted after Hoffert and Flannery (1985).

\begin{tabular}{c||rc}
\hline $\mathrm{B}$ & 2.2 & $\mathrm{~W} / \mathrm{m}^{2} / \mathrm{K}$ \\
$\mathrm{K}$ & 7.93 & \\
$\mathrm{C}_{\mathrm{N}}$ & 8.13 & $\mathrm{~W} \cdot \mathrm{yr} / \mathrm{m}^{2} / \mathrm{K}$ \\
$\mathrm{C}_{\mathrm{S}}$ & 10.79 & $\prime \prime$ \\
$\mathrm{C}_{\mathrm{a}}$ & 9.46 & $\prime \prime$ \\
\hline
\end{tabular}

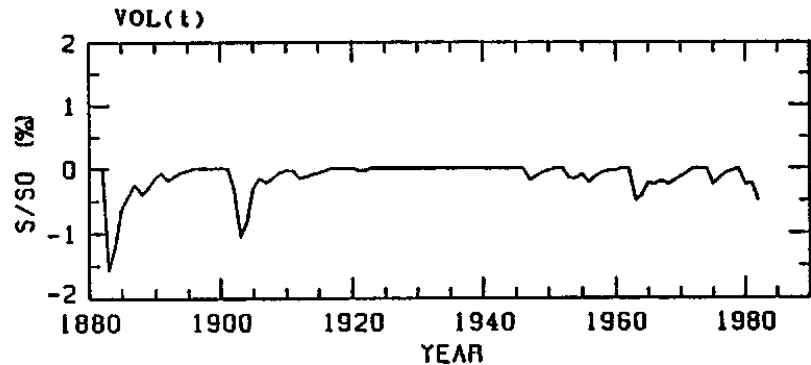

Fig. 2. Time evolution of $\operatorname{VOL}(t)$ expressed by percent of the solar input for the duration $t=1880$ to 1982 (See details in Section 2).

$\operatorname{VOL}(t)$ is a function expressing the volcanic activity based on the DVI (Lamb, 1970; Mitchell, 1970, 1982; Robock, 1978), which is scaled by assuming the Agung dust produced a $0.5 \%$ decrease in solar constant following Robock (1978) (Fig. 2). Here, because of its convenience in quantitative treatments, we use the DVI in several indices of the volcanic activity such as DVI (Lamb, 1970), VEI (Simkin et $a l ., 1981$; Newhall and Self, 1982), and a record of electrolytic conductivity (Hammer, 1977). $\operatorname{RAD}(t)$ (Fig. 3) represents the variation of direct solar radiation given in Loginov (1984), assuming that $6 \%$ decrease of direct radiation corresponds to $1 \%$ of total solar radiation, following Budyko (1977). It can be noted that, although atmospheric dust concentrations south of about $30^{\circ} \mathrm{N}$ have not increased except 
the stations near big urban cities or industrial areas (Machta and Telegadas, 1974), particle concentrations have increased in the most part of the northern temperate latitudes since the 1940 s and the direct solar radiation has sensibly decreased (Budyko, 1977). In both functions, arbitrary scaling is used for the comparison of relative magnitude. We will determine the coefficient $F_{\mathrm{VOL}}$ or $F_{\mathrm{RAD}}$ in the following way.

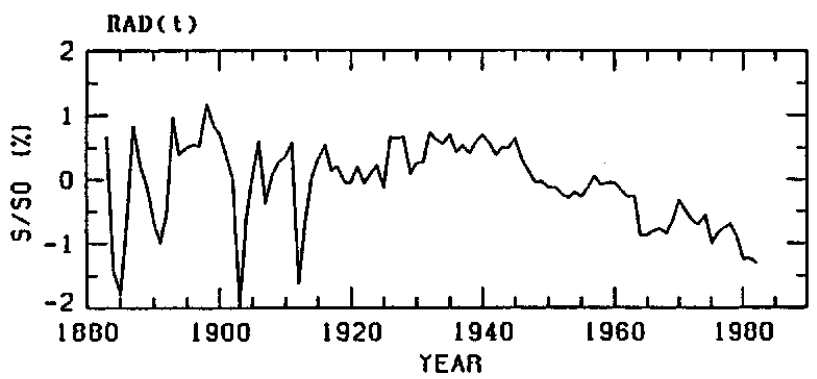

Fig. 3. Time evolution of $\operatorname{RAD}(t)$ in percent of the solar input for the duration $t=1883$ to 1982 (See details in Section 2).

We integrate numerically each equation from $t=$ 1870 to 1982 by setting $x=0$ at $t=1870$ (if $\operatorname{VOL}(t)$ or $\operatorname{RAD}(t)$ is not available, we assume it zero). Then we calculate the anomaly from the mean of $t=1951$ to 80 , and the difference between the model-result and the observed-temperature data during $t=1883$ to 1982 . We repeat this calculation changing the value of $F_{\mathrm{CO}_{2}}$ and $F_{\mathrm{VOL}}$ or $F_{\mathrm{RAD}}$ so as to minimize the sum of squared difference values. The results will be described in the next section.

\subsection{Observed temperature data}

In the present work we will use two time series of annual mean surface air temperature: N.H. and S.H. mean temperature during the period from 1851 to 1984 estimated by Jones et al. (1986a, b) (referred as Jones' data); and N.H., S.H. and global mean air temperature from 1880 to 1987 estimated by Hansen and Lebedeff $(1987,1988)$ (referred as Hansen's data).

In Fig. 4, these time series are expressed by the anomaly from the mean during the period 19511980 , because the mean temperature of both groups during the period was estimated from dense network data and they may not depend on the method of estimation. The Northern Hemisphere values of Jones' are systematically higher than those of Hansen's, but the difference is small after about 1930 . On the contrary, the Southern Hemisphere values of Jones' are lower before about 1940 , and the difference is not small even in recent years. But the S.H. mean value is not so significant as the N.H. mean because of the insufficient number of observation. The difference of the global mean value is the smallest in the three cases.

\section{Results}

In this section, we will first give the results of Nicolis' model with some comments and the results of the modified model, and estimate the effects of several factors.
TE MPEFATUAE IAEF. 1851-801
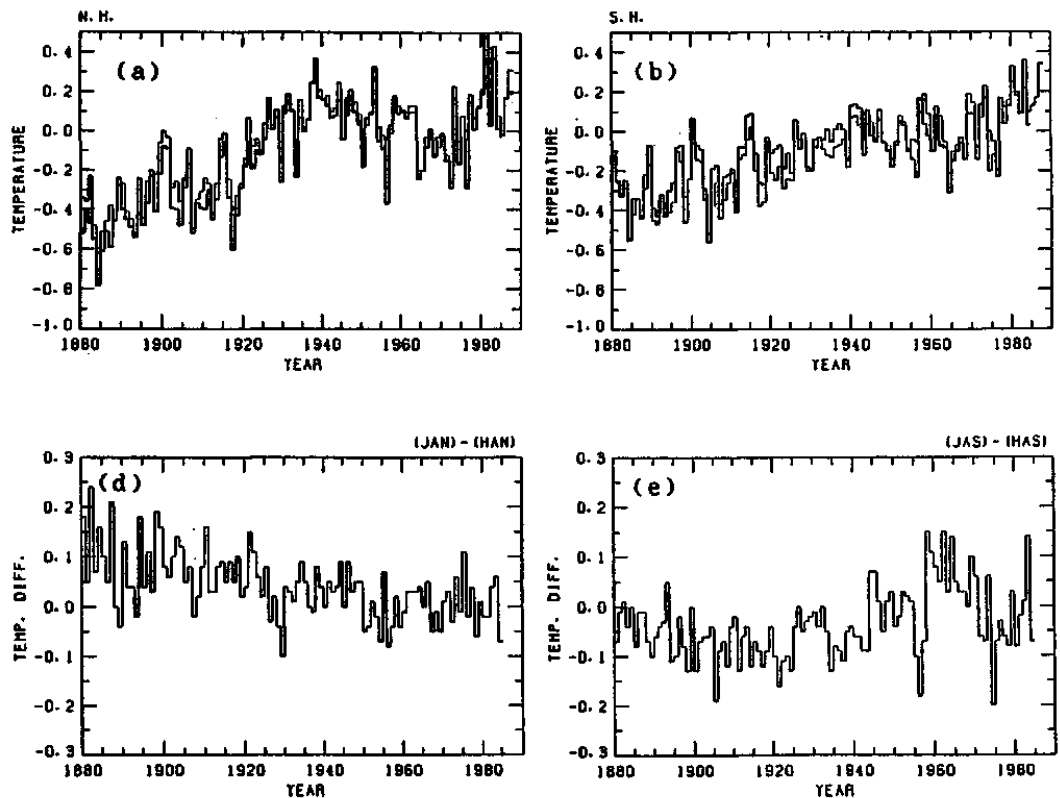

TEMPERATUAE IREF-1951-80

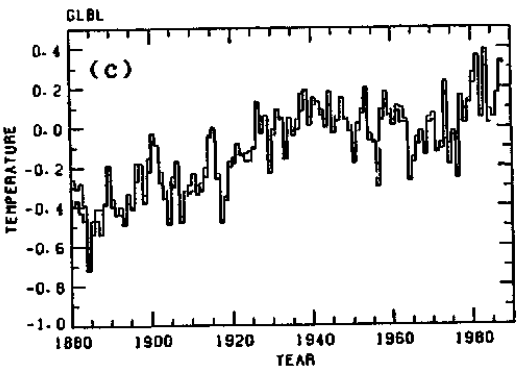

TE TPEARTURE IREF. 1851-80I

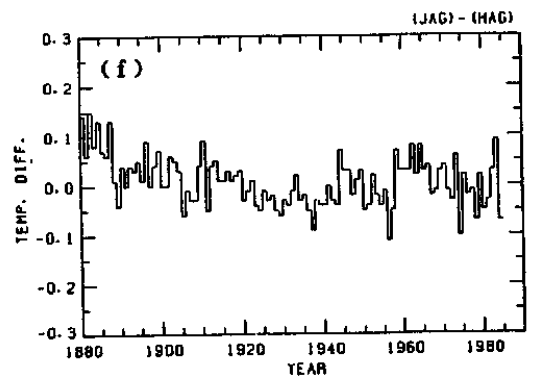

Fig. 4. Time evolution of the N.H. (a), the S.H. (b), and global (c) mean surface air temperature anomaly from the 1951-80 mean by Jones' data (thin line) and Hansen's data (heavy line), and the difference of the two time series (Jones' data-Hansen's data) for the respective area (d, e and f). Unit is K. 


\subsection{Results of Model I (Nicolis' model)}

Nicolis (1988) shows that the variance of variable $x$ in the Eq. (2-1) is constant for additive noises, and that it increases for multiplicative ones. From this, she concluded the interesting possibility that we may detect the heating effect of $\mathrm{CO}_{2}$ by the increase of temperature variance. However, we have a few comments on her results and conclusion.

Nicolis (1988) calculated the variances at each time point from the ensembles of $x(t)$ forced by various time series of $F(t)$. Figure 5 shows the examples of the calculation with the additive white noise (a) and multiplicative white noise (b). As might be expected, in Fig. 5a the variance reaches the constant value soon after the relaxation time of the system (4 years), while in Fig. $5 \mathrm{~b}$ it gradually increases in proportion to $t^{2}$.

The observed global mean temperature data, however, consists of only one time series. Then the variance of the global mean temperature at each time is estimated in the following way: we calculate a variance from the temperature data for a time interval and define it as the variance of the centered time of the interval. Figure 6 shows the examples of time series of temperature and those of its variance: we adopted one of 200 time series of forcing function $F(t)$ used in Fig. 5. In Fig. 6c, the variance may change in a certain range, but the magnitude of fluctuation is so large that we cannot be confident that the variance is constant. In Fig. 6d, we can detect the systematic increase of the variance on the time scale of more than a hundred years, but can not distinguish over several decades from that of the additive noise case.

The results for the red noise case (not shown here) are similar to those in the white noise case.

On the other hand, Angell and Korshover (1977) concluded from the temperature data that the
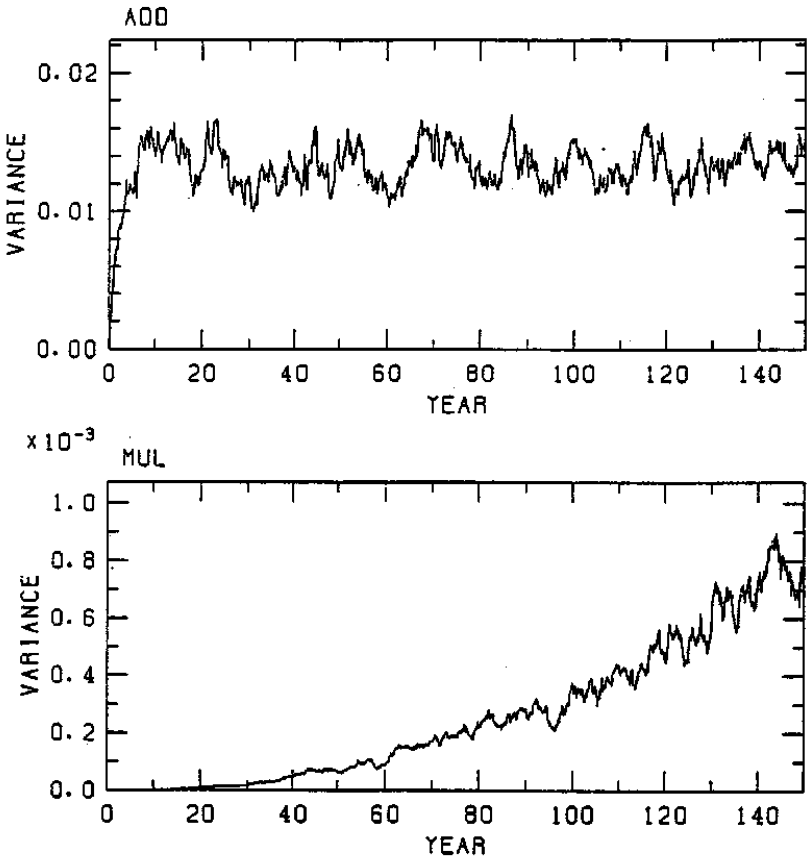

Fig. 5. Time evolution of ensemble variance of the Nicolis (1988) model results with 200 different additive white noises (a) and multiplicative ones (b): $q^{2} / C^{2}=6.9 \times 10^{-3}\left(q^{2}\right.$ is the variance of $F(t)$.), where the variance is the same as Nicolis'.

temperature variance was increasing between 1958 and 1975. This length of data is insufficient for a definitive conclusion. Figure 7 shows two time series of variance during the last hundred years: one is based on the temperature data from Hansen and Lebedeff $(1987,1988)$, and another from Jones et al. (1986a, b). Roughly speaking, these two variances coincide: the variance was large in the $1920 \mathrm{~s}$, and small in the 1940s, and increased after about 1950.
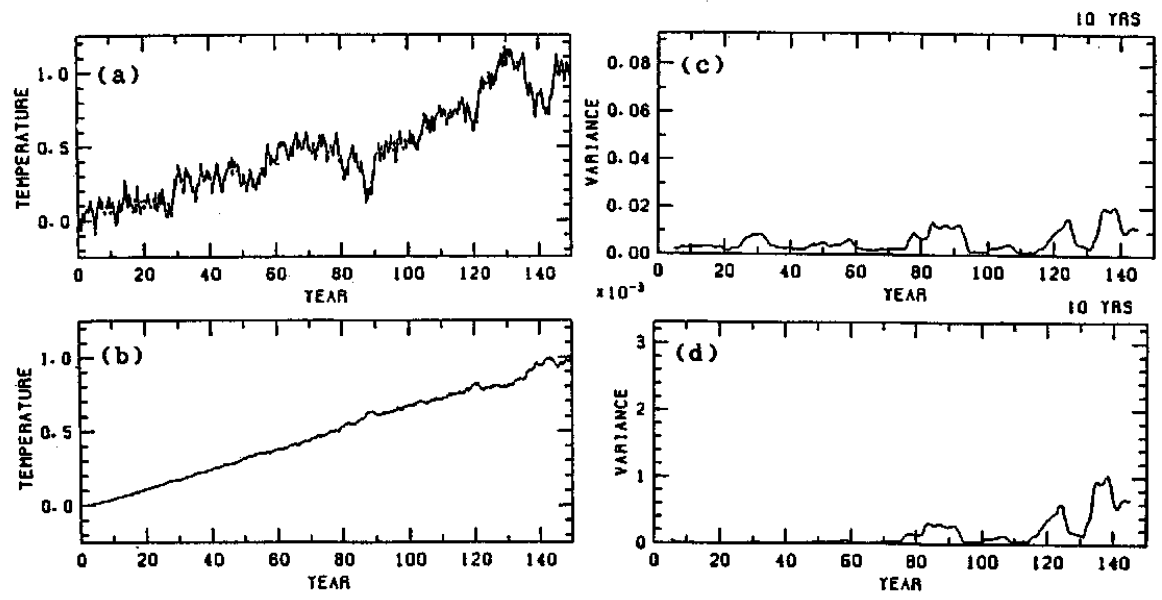

Fig. 6. Time evolution of a variable $X$ in the Nicolis model with an additive white noise (a) and multiplicative one (b). Here we used one of 200 time-series $F(t)$ in Fig. 5 . Figures 6 (c) and (d) show time evolution of the variance for each 10 years (containing 201 time points) of the time series (a) and (b), respectively. 
From these results we can not draw a conclusion that the temperature variance is monotonically increasing. In the observational results of Hoshiai (1984), we cannot find the long-term increase of the standard deviation of the N.H. mean surface air temperature, especially before the $1950 \mathrm{~s}$. The above time series of the variance can be a part of a long time series in either type of noise, additive or multiplicative. From the variance during the recent hundred years that remained in a certain range, we may conclude that these year-to-year temperature variations are caused mainly by an additive noise.

Nicolis (1988) did not take account of any explicit external causes except $\mathrm{CO}_{2}$ heating: the volcanic activity, however, may be a key factor to the decadal change of temperature. Although eruptions may occur with random intervals, time intervals for high and low volcanic activity found in the record of eruptions (see Fig. 2) are about 1-2 decades. Therefore, we will examine both the effects of $\mathrm{CO}_{2}$ heating and volcanic activity, using observed temperature data and the modified model.

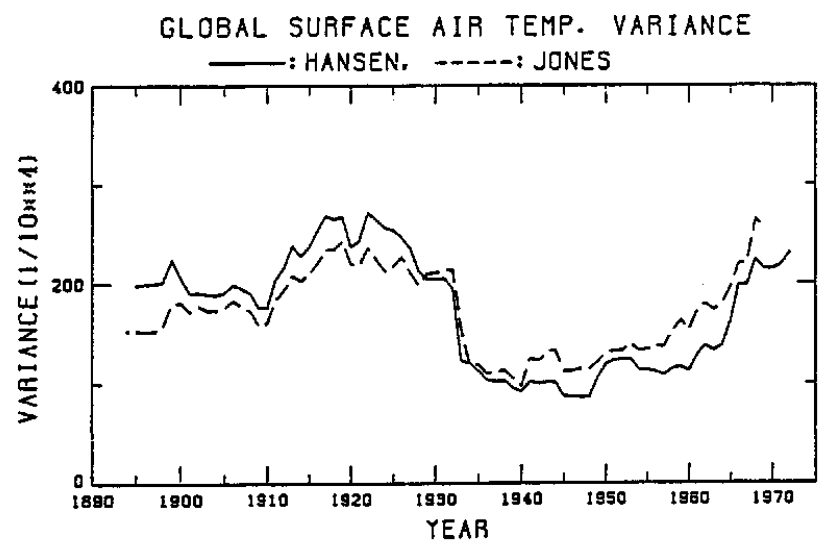

Fig. 7. Time evolution of variance calculated from the observed global mean temperature data by Jones (broken line) and Hansen (solid line) for each 30 years during the years $1895-1970$.

\subsection{Results of Model II (modified model)}

a) $\mathrm{CO}_{2}$-only case

In this case we use Model II and treat the $\mathrm{CO}_{2}$ effect as the external cause. Results show that there must be another factor which cause a systematic change in temperature variation.

We compare the observed temperature variation with the model result based on the values of $\mathrm{F}_{\mathrm{CO}_{2}}$ in Table 3 (Fig. 8). Figures 8a, b and $\mathrm{c}$ are the results for the N.H., the S.H. and the global mean, respectively. The difference between the observed and computed time series is shown in Figs. 8d, e and $f$ with an 11-year running mean values. The standard deviation during the same 11 years is also shown for both sides of the mean value. The figures in this section are compared with Jones' data unless any comments are given.

As seen in Table 3, the value of $F_{\mathrm{CO}_{2}}$ in the N.H. for Jones' data is larger than that for Hansen's data, while it is opposite in the S.H. This is easily deduced from the difference between these two data as was commented in Section 2. We may assume that the real temperature variation lies between them. Then the most appropriate value of $\mathrm{F}_{\mathrm{CO}_{2}}$ may be about 0.6 , meaning that Hoffert and Flannery (1985) overestimated the value of $K$, if our assumption about the heat capacity is valid.

In Fig. 8, as the concentration of $\mathrm{CO}_{2}$ increases, the global mean temperature calculated in the model increases by about $0.37 \mathrm{~K}$ during the recent hundred years. The difference between the model result and the observed data shows a systematic change: minimum in about 1910 and 1970 , and maximum in about 1940, and this is more remarkable in the Northern Hemisphere. In the Southern Hemisphere, the observed temperature increases more steadily than in the Northern Hemisphere, but with a rather smaller amplitude and the same phase.

Nicolis (1988) suggested that a long-lived variation can be caused by a stochastic forcing, if the variance of the forcing is large enough. But in the present case, the variation is too systematic to be caused by a random noise, and it has a time scale of several decades.

Therefore there must be another factor to be considered, and next we treat the volcanic activity as an external cause of the variation.

\section{b) " $\mathrm{CO}_{2}+$ volcanic activity" case}

In this case we use Model II and take account of the effects of $\mathrm{CO}_{2}$ and volcanic activity. Table 3 gives the values of $\mathrm{FCO}_{2}$ and $F_{\mathrm{VOL}}$, and Fig. 9 compares the model results with the observed data as was done in Fig. 8.

In Fig. 9, the phase of temperature change in the model results is in good agreement with that of the observed data. The systematic change in the difference between the two time series is smaller than that of the $\mathrm{CO}_{2}$-only case in the N.H. and global mean, and almost negligibly small in the Southern Hemisphere.

The value of $F_{\mathrm{CO}_{2}}$ is roughly 0.5 (Table 3 ), which is smaller than in the case (a). The temperature increase due to the $\mathrm{CO}_{2}$ effect might be small if the low temperature observed in 1880s and in 1900s may be attributed to the strong volcanic activity.

$F_{\text {VOL }}$ is about $0.84-0.9$ for the N.H., $0.7-0.83$ for the global mean, and $0.5-0.56$ for the S.H.; with a large difference between the values of each hemisphere.

From these results, it is concluded that volcanic activity is one of the important causes of the cli- 
Table 3. The most reasonable values of $F_{\mathrm{CO}_{2}}, F_{\mathrm{VOL}}$ and $F_{\mathrm{RAD}}$ : the variance of differences between the model results and the observed temperature data; and the estimated magnitude of the stochastic forcing in the form of $q / S_{0}(\%)$. The respective conditions correspond to the model Eq. (2-2), (2-3) and (2-4). Columns J and H represent Jones' and Hansen's data, respectively (details are given in the text).

\begin{tabular}{|c|c|c|c|c|c|c|c|}
\hline condition & area & $\begin{array}{l}\text { data } \\
\mathrm{J} / \mathrm{H} \\
\end{array}$ & $F_{\mathrm{CO}_{2}}$ & $F_{\text {VOL }}$ & $\overline{F_{\text {RAD }}}$ & $\begin{array}{l}\text { variance of } \\
\text { difference }\end{array}$ & $\begin{array}{c}q / S_{0} \\
(\%)\end{array}$ \\
\hline \multirow{6}{*}{$\mathrm{CO}_{2}$ only } & \multirow[t]{2}{*}{$\overline{\mathrm{NH}}$} & $\overline{\overline{\mathbf{J}}}$ & $\overline{0.50}$ & & & $\overline{4.09 \times 10^{-2} \mathrm{~K}^{2}}$ & 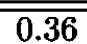 \\
\hline & & $\mathbf{H}$ & 0.67 & & & 4.11 & 0.36 \\
\hline & \multirow[t]{2}{*}{ SH } & $\bar{J}$ & 0.65 & & & 1.78 & 0.27 \\
\hline & & $\bar{H}$ & 0.48 & & & 1.76 & 0.27 \\
\hline & \multirow[t]{2}{*}{ global } & $\mathbf{J}$ & 0.58 & & & 2.33 & 0.29 \\
\hline & & $\mathbf{H}$ & 0.61 & & & 2.73 & 0.31 \\
\hline \multirow{6}{*}{$\begin{array}{c}\mathrm{CO}_{2} \\
+ \\
\text { volcano }\end{array}$} & \multirow[t]{2}{*}{ NH } & $\mathbf{J}$ & 0.39 & 0.86 & & 2.47 & 0.28 \\
\hline & & $\overline{\mathrm{H}}$ & 0.55 & 0.90 & & 2.37 & 0.27 \\
\hline & \multirow[t]{2}{*}{$\overline{\mathrm{SH}}$} & $\mathrm{J}$ & 0.58 & 0.50 & & 1.36 & 0.24 \\
\hline & & $\bar{H}$ & 0.40 & 0.56 & & 1.22 & 0.22 \\
\hline & \multirow[t]{2}{*}{ global } & $\bar{J}$ & 0.48 & 0.71 & & 1.37 & 0.22 \\
\hline & & $\overline{\mathrm{H}}$ & 0.50 & $0.8 \overline{3}$ & & 1.40 & $0.2 \overline{2}$ \\
\hline \multirow{6}{*}{$\begin{array}{c}\mathrm{CO}_{2} \\
+ \\
\text { radiation }\end{array}$} & \multirow[t]{2}{*}{$\mathrm{NH}$} & $\mathrm{J}$ & 1.03 & & 0.35 & 2.28 & 0.26 \\
\hline & & $\bar{H}$ & 1.16 & & 0.32 & 2.22 & 0.26 \\
\hline & \multirow[t]{2}{*}{ SH } & $\mathbf{J}$ & 0.91 & & 0.18 & 1.40 & 0.24 \\
\hline & & $\mathrm{H}$ & 0.74 & & 0.19 & 1.41 & 0.24 \\
\hline & \multirow[t]{2}{*}{ global } & $\mathbf{J}$ & 0.95 & & 0.25 & 1.36 & 0.22 \\
\hline & & $\mathbf{H}$ & 1.01 & & 0.27 & 1.50 & 0.23 \\
\hline
\end{tabular}
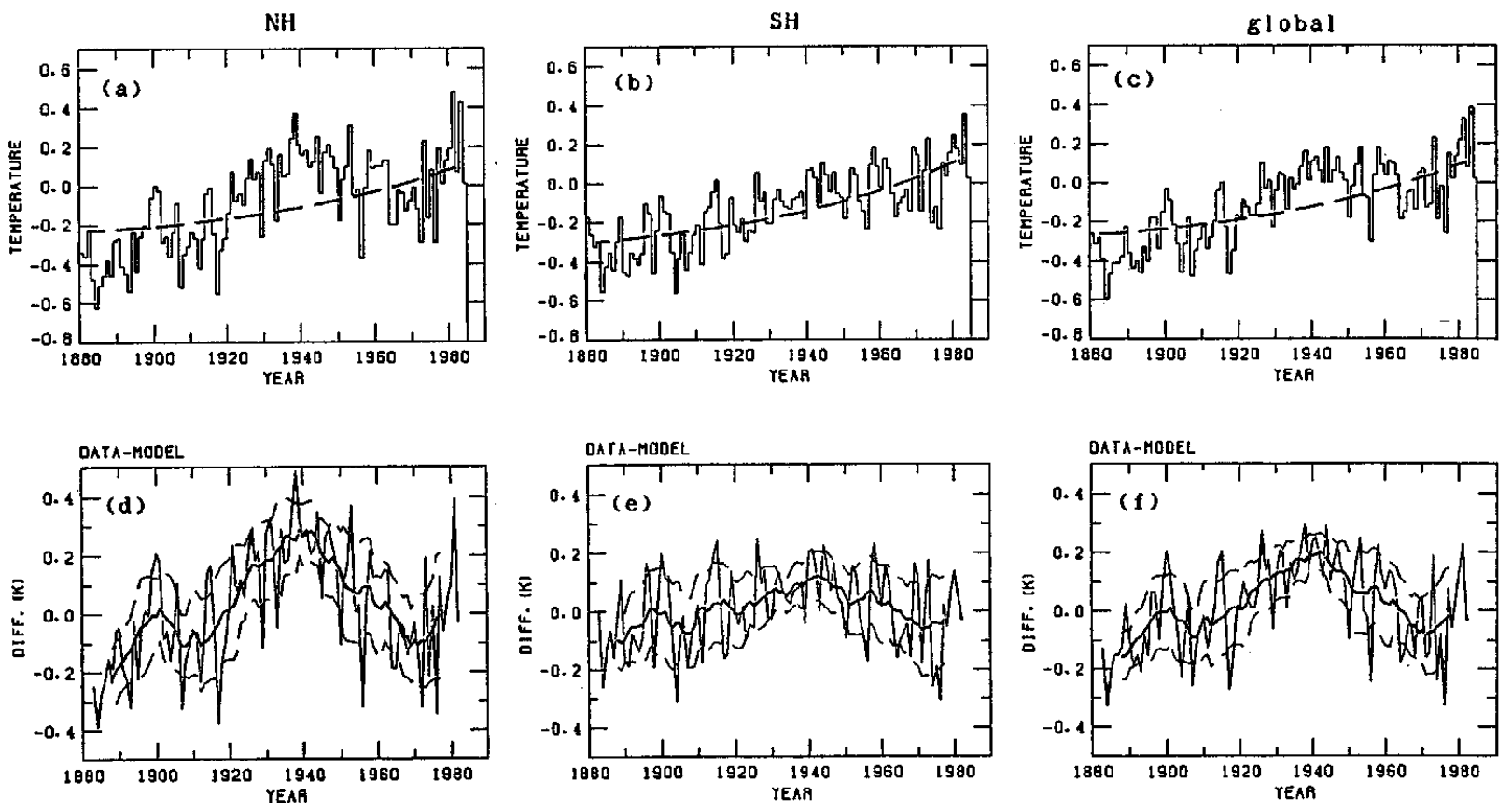

Fig. 8. Comparison of Jones' temperature data (solid line) and the model result (broken line) for the $\mathrm{CO}_{2}$ only case in the N.H. (a), the S.H. (b) and the entire globe (c). Difference between the two time series, (d), (e) and (f) for the respective area: Heavy and broken lines denote 11-year running mean value and broken lines denote a standard deviation from the running average, respectively. Unit is $\mathrm{K}$. 
(REF. 1951-1980)
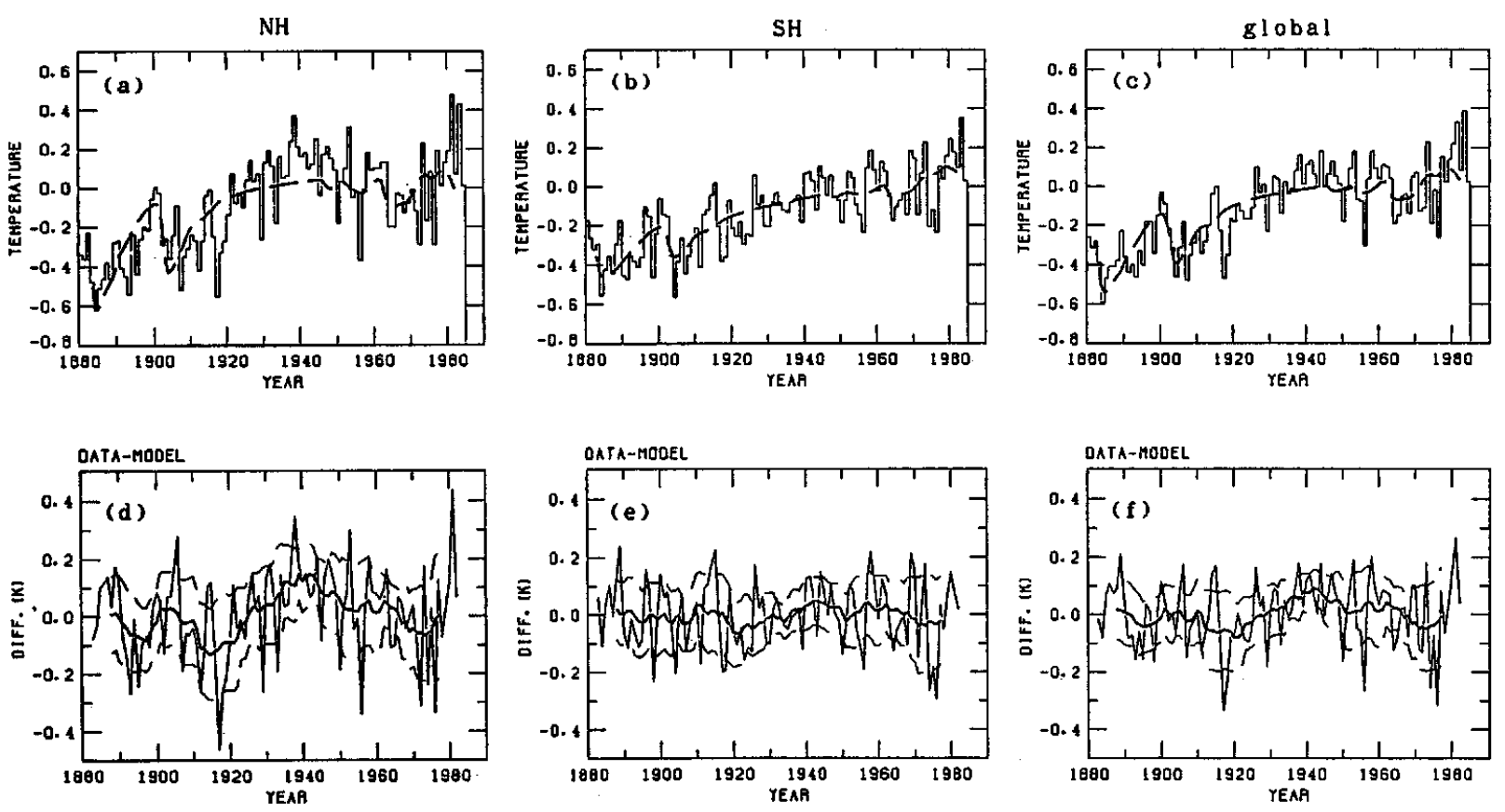

Fig. 9. The same as Fig. 8, except for the " $\mathrm{CO}_{2}+$ volcanic activity" case.

matic change, and that it intermittently dominates the temperature variation with time scale of a few decades. Although each eruption occurs with nearly random time interval, the activity with a certain time scale must have a large effect on the climatic change.

The difference between the values of $F_{\mathrm{VOL}}$ in the respective hemispheres may be attributed to the fact that the large eruptions concentrated in the Northern Hemisphere (see, for example, Newhall and Self (1982): 52 large eruptions have occurred during the period of $1880-1980 ; 36$ in the N.H., and 12 in the equatorial Southern Hemisphere $\left(0^{\circ}-10^{\circ} \mathrm{S}\right)$ ). The volcanic aerosols may be distributed more in the N.H. than in the S.H., and the volcanic effect is larger in the N.H. than in the S.H. The volcanic effect seems small in the S.H. (Fig. 9).

\section{c) "CO $\mathrm{O}_{2}+$ solar radiation" case}

In this case we use the model Eq. (2-4), and the results are shown in Table 3 and Fig. 10. We pay attention to the results corresponding to the N.H., because the direct solar radiation data are limited in the N.H. as commented in Section 2. In fact the values of $F_{\mathrm{RAD}}$ for the S.H. are rather small, even though there is no systematic change in the difference between the model result and the observed data. This is due to the fact that RAD ( $t$ ) contains the effect of volcanic activity.

In Fig. 10, the systematic change in the difference of two time series is the smallest in the three cases in the N.H. and global mean. In this case, the tempe- rature decrease after 1940 is clearly explained by the decrease of solar radiation, even though the reason why the radiation decreased is not clear. It was not completely explained by the volcanic activity in the Case (b), so that the effect of anthropogenic aerosol increase may not be negligible.

As is seen in Table 3, the value of $\mathrm{F}_{\mathrm{CO}_{2}}$ for the present case is about 1.0 , which is very large compared with those of Cases (a) and (b): the net $\mathrm{CO}_{2}$ heating effect is large so as to cancel out the large effect of radiation decrease after 1940 , which continues to the end of the period of our concern.

The value of $F_{\mathrm{RAD}}$ is about 0.35 for the N.H., and about 0.25 for the global mean. The values of $F_{\mathrm{RAD}}$ should have no large differences for both hemisphere. Therefore, the above difference of $F_{\mathrm{RAD}}$ may be attributed to the fact that the conversion rate of a $6 \%$ decrease in the direct solar radiation to a $1 \%$ decrease of total radiation, estimated from the data in the Northern Hemisphere, is rather small.

The above-mentioned results suggest that the anthropogenic aerosols have some effects on the climatic change, but the effect can not be separated from that of volcanic activity which causes a large systematic temperature change seen in Case (b). We should note, however, that we cannot conclude from our results to what extent the anthropogenic aerosols have an effect on the recent climatic change.

\section{Discussion}

In this section we will discuss the magnitude of stochastic forcing and the "detectability" of the 

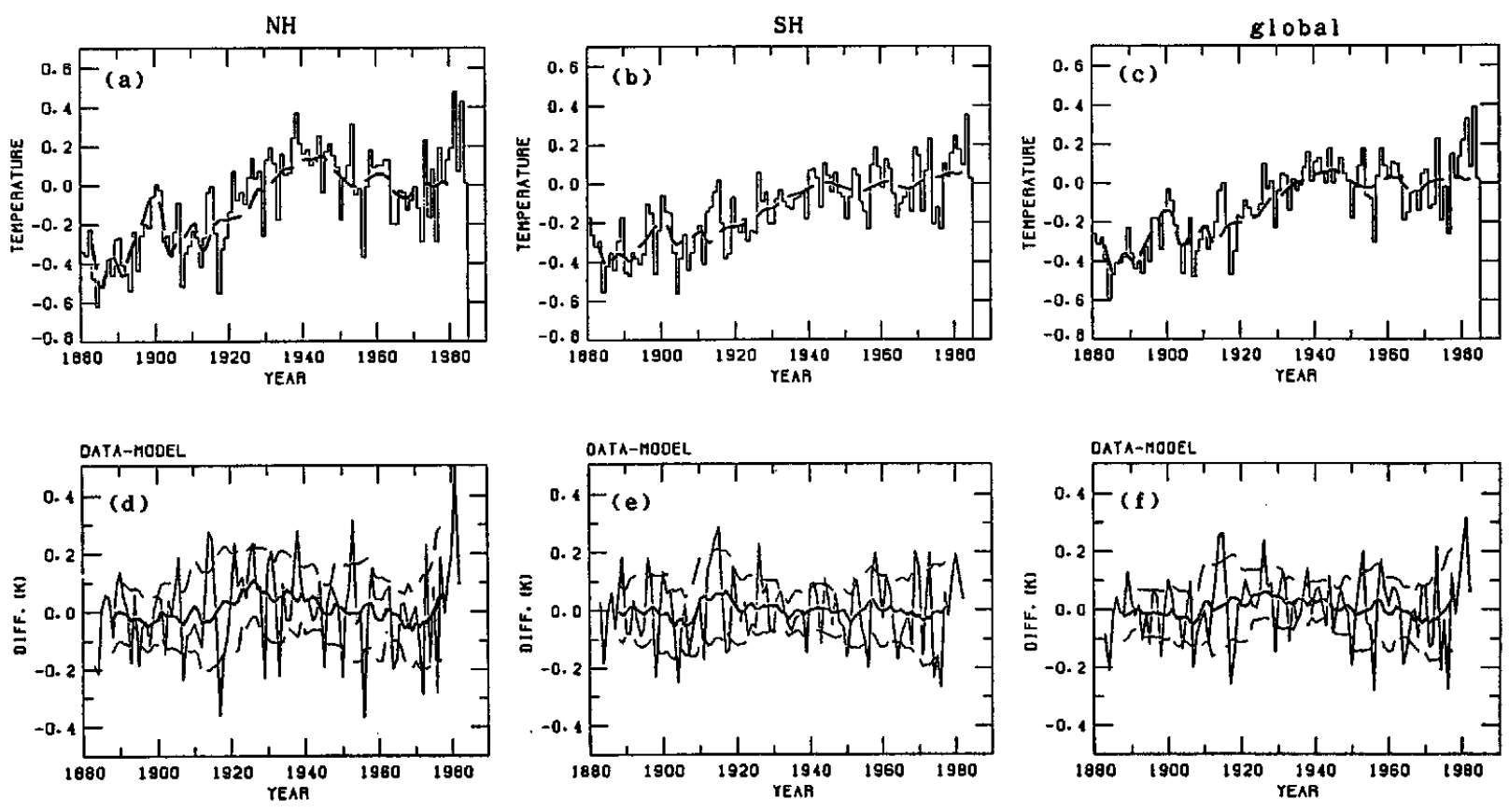

Fig. 10. The same as Fig. 8, except for the " $\mathrm{CO}_{2}+$ solar radiation" case.

temperature increase due to the $\mathrm{CO}_{2}$ effect.

\subsection{The magnitude of stochastic forcing}

Figures 8, 9 and 10 illustrate year-to-year variations in the differences between the model results and the observed data. The difference might be attributed to the stochastic forcing, whose magnitude is estimated from the variances of these differences as follows: we assume these variances are due to additive white noise as commented in Section 3.1, and use the next equation presented by Nicolis (1988) which is valid for our modified model $(2-2 \sim 2-4$, with a stochastic forcing term):

$$
\overline{\delta x^{2}}=\frac{q^{2}}{2 \lambda C^{2}}
$$

where $\overline{\delta x^{2}}$ is an ensemble variance of the variable $x$ and $q^{2}$ is a variance of the Gaussian white noise. $F(t), \lambda$ and $C$ are given in Eq. (2-1). We replace $\overline{\delta x^{2}}$ and $\lambda$ by the variance of the differences, and $B / C$ respectively, and calculate $q^{2}$.

The values $q^{2}$ are listed in Table 3 in the form of $q / S_{0}$ where $S_{0}=340 \mathrm{~W} / \mathrm{m}^{2}$ is the solar constant divided by 4 . The magnitude of the stochastic forcing ranges from $0.27-0.36 \%$ for the case of $\mathrm{CO}_{2}$ effect only, and $0.22-0.28 \%$ for the other two cases.

In the case of $\mathrm{CO}_{2}$ only, the value $q / S_{0}$ includes the contribution from volcanic activity, and it is larger than that of other cases. Therefore we take $0.22-0.28 \%$ of solar input as the magnitude of stochastic forcing. According to Willson and Hudson (1988), the amplitude of the solar activity variation is less than $0.1 \%$. Therefore there must exist another cause. Moreover considering that the value $q / S_{0}$ for the N.H. is larger than that for the S.H., the main cause of the stochastic forcing may exist within the earth climate system, such as atmosphere-ocean non-linear interaction. Hansen et al. (1988b) illustrated by the more sophisticated model that internal causes may account for a large portion of the recent variability.

\subsection{The "detectability" of warming due to $\mathrm{CO}_{2}$ - loading}

It is uncertain that the global mean surface air temperature has significantly increased due to the $\mathrm{CO}_{2}$ greenhouse effect during the recent hundred years, even though the observed data appears to show an increasing trend. First, we cannot rely sufficiently on the observed temperature data before about 1900: Secondly, the year-to-year variation is large. In Fig. $8 \mathrm{c}$ the temperature increase due to the $\mathrm{CO}_{2}$ effect in the model results is about $0.37 \mathrm{~K}$; the standard deviation of the difference between the simulated and observed temperature data is about $0.15 \mathrm{~K}$ (Table 3 ). If we adopt the confidence limit of $95 \%$, the confidence intervals of $2 \times$ S.D. at the beginning and end of the hundred year period are overlapped: it may be significant with at most a 78 $\%$ confidence limit.

Therefore we will estimate when a significant temperature increase becomes detectable in the future. A standard temperature is taken to be the global and 1951-80 time-mean value from Jones' data. We extend the numerical integration until 
(REF. 1951-1980)
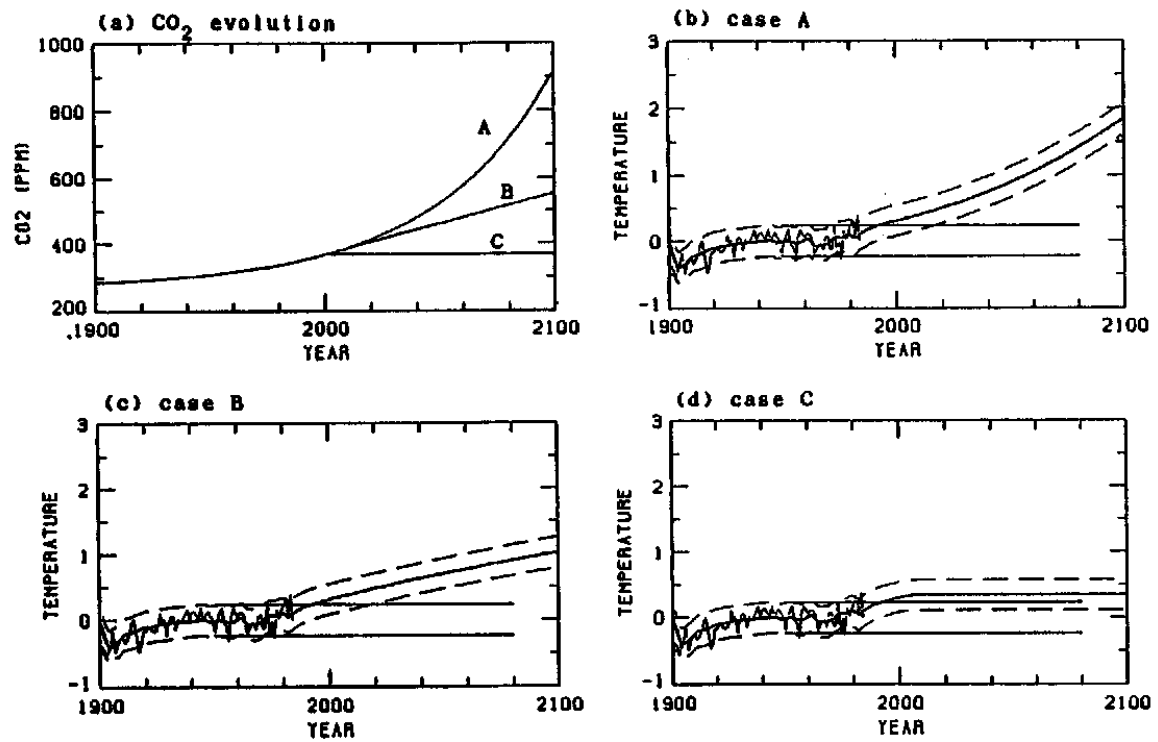

Fig. 11. Three cases of the $\mathrm{CO}_{2}$ time evolution $\mathrm{A}, \mathrm{B}$ and $\mathrm{C}(\mathrm{a})$, and corresponding temperature evolution (heavy line) with $\pm 2 \sigma$ lines (broken line) and Jones' data for the global mean: (b), (c) and (d) for the Cases A, B and C, respectively. The thin lines indicate the mean values during years 1951 to 1980. Unit is K. (See details in Section 4)

2100 using our modified model (2-3) with $F_{\mathrm{CO}_{2}}$ and $F_{\text {VOL }}$ obtained for Jones' global mean data. As for the volcanic activity, we assume no large and continuing eruptions will occur after 1983 for lack of information.

Three cases of the $\mathrm{CO}_{2}$ time evolution are considered (Fig. 11a): in Case $\mathrm{A}, \mathrm{CO}_{2}$ concentration continues to increase following the equation presented by Hoffert and Flannery (1985); in Case $\mathrm{B}, \mathrm{CO}_{2}$ continues to increase but linearly after 2000 (about 1.9 $\mathrm{ppmv} / \mathrm{yr}$ ); in Case $\mathrm{C}, \mathrm{CO}_{2}$ stops to increase at 2000 , and hold the value (about $368 \mathrm{ppmv}$ ) after that.

Figures 11b, $c$ and $d$ show the results for the three cases A, B and C, respectively. The confidence limit is taken to be about $95 \%$ and $\pm 2 \sigma$ lines ( $\sigma$ : standard deviation of the differences between the model result and the observed data for the duration 1882-1983) are also shown for both extended model results and for the 1951-80 mean temperature.

In Case A, the confidence interval of the model result is clearly distinguished from that of the standard temperature by about 2020 , and a nearly $2 \mathrm{~K}$ increase in the global temperature is expected by the end of next century, while the $\mathrm{CO}_{2}$ concentration increases up to $900 \mathrm{ppmv}$ in that duration. In Case B, the separation of the confidence interval from the 1951-80 mean occurs at almost same time as for Case A: the increase is about $1 \mathrm{~K}$ by 2100 , and $\mathrm{CO}_{2}$ increases up to $550 \mathrm{ppmv}$. In Case $\mathrm{C}$, the model results reaches a constant value (about $0.35 \mathrm{~K}$ ) soon after $\mathrm{CO}_{2}$ stops to increase. In this case, a significant increase in the global mean temperature is not detected.

From these results, assuming that $\mathrm{CO}_{2}$ increases between that of Cases $\mathrm{A}$ and $\mathrm{B}$, and that no large eruptions occur in the next thirty years, we may be able to detect a significant temperature increase due to the $\mathrm{CO}_{2}$ effect by about 2020 , and there will be a global temperature increase of $1-2 \mathrm{~K}$ by the end of the next century.

Moreover the model results show that the temperature rises beyond the confidence limit of 1951-80 mean temperature in the $1990 \mathrm{~s}$. Since there were no large eruptions except El Chichon (1982) in 1980s, and the warmest year in the global mean temperature after 1900 is 1987 followed by 1983 and 1981 (Jones and Kelly, 1988), relatively higher temperatures might be expected as early as in the next decade.

\section{Conclusion}

Using an energy balance model and observed surface air temperature data, we have studied the effects of several internal and external causes of the earth climate change for the recent hundred years.

The main conclusions in the present work are as follows:

(1) The effect of $\mathrm{CO}_{2}$ increase is important on a time scale longer than a decade. We cannot conclude at present that the global mean surface air temperature has shown a statistically significant increase with $95 \%$ confidence limit; but we may conclude that the temperature increase is significant with at most a $78 \%$ confidence limit. If there are no large 
eruptions in the next thirty years, we may detect the warming due to the increase of $\mathrm{CO}_{2}$ in the global mean surface air temperature.

(2) Volcanic activity in the last hundred years had an effect on the global temperature change with a decadal time scale, especially in the Northern Hemisphere, but it intermittently affected the temperature variation.

(3) The effect of direct solar radiation is also studied. The model result may explain the temperature decrease observed after 1940 in the Northern Hemisphere. An effect of anthropogenic aerosols on the earth climate should be taken into consideration, especially in the recent decadal climatic change.

(4) During the recent hundred years, the temperature variance has not increased monotonically, but has remained in a certain range: this fact does not support the conclusion of Nicolis (1988). It was estimated from the observed and model simulated data that the magnitude of stochastic forcing is about $0.22-0.28 \%$ of solar radiation at the top of the atmosphere. Considering that the magnitude of stochastic forcing for the Northern Hemisphere is larger than that for the Southern Hemisphere, the main causes of year-to-year temperature change may lie within the earth climate system.

Here, we have not explicitly treated the nonlinear processes due to coupling temporal and spatial scales of the atmosphere as was discussed by Lin and Koshyk (1978), which is one of the future problems to be investigated.

(5) Finally, from the above results we may conclude the relative role of the external and internal causes in the long term variation of temperature: there is a warming trend due to $\mathrm{CO}_{2}$ as a background change, intermittent and decadal variation mainly due to the volcanic activity, and year-to-year change due to a stochastic forcing which may originate from internal causes.

\section{Acknowledgements}

We wish to express our hearty gratitude to Professor Ryozaburo Yamamoto for continuing guidance, encouragement and critical reading of the manuscript. Thanks are also extended to Dr. SangaNgoie Kazadi of Nagoya International Center and the members of Laboratory for Climatic Change Research, Faculty of Science, Kyoto University.

The computation was performed on the FACOM M730/10 computer at Laboratory for Climatic Change Research of Kyoto University.

\section{References}

Angell, J.K. and J. Korshover, 1977: Estimate of the global change in temperature, surface to $100 \mathrm{mb}$, between 1958 and 1975. Mon. Wea. Rev., 105, 375385.
Augustsson, T. and V. Ramanathan, 1977: A radiativeconvective model study of the $\mathrm{CO}_{2}$ climate problem. J. Atmos. Sci., 34, 448-451.

Budyko, M.I., 1969: The effect of solar radiation variations on the climate of the earth. Tellus, 21, 611619.

Budyko, M.I., 1977: On the present-day climatic changes. Tellus, 29, 193-204.

Gilliland, R.L., 1982: Solar, volcanic, and $\mathrm{CO}_{2}$ forcing of recent climatic changes. Climatic Change, 4, 111131.

Hammer, C.U., 1977: Past volcanism revealed by Greenland ice sheet impurities. Nature, 270, 482-486.

Hansen, J., D. Johnson, A. Lacis, S. Lebedeff, P. Lee, D. Rind and G. Russel, 1981: Climate impact of increasing atmospheric carbon dioxide. Science, $\mathbf{2 1 3}$, 957-966.

Hansen, J. and S. Lebedeff, 1987: Global trends of measured surface air temperature. J. Geophys. Res. 92, 13345-13372.

Hansen, J. and S. Lebedeff, 1988: Global surface air temperatures: update through 1987. Geophys. Res. Lett., 15, 323-326.

Hansen, J., I. Fung, A. Lacis, D. Rind, S. Lebedeff, R. Ruedy and G. Russel, 1988b: Global climate change as forecast by Goddard Institute for Space Studies three-dimensional model. J. Geophys. Res., 93, 9341-9364.

Harvey, L.D.D. and S.H. Schneider, 1985a: Transient climate response to external forcing on $10^{0}-10^{4}$ year time scales. Part 1: Experiments with globally averaged, coupled, atmosphere and ocean energy balance models. J. Geophys. Res., 90, 2191-2205.

Harvey, L.D.D. and S.H. Schneider, 1985b: Transient climate response to external forcing on $10^{\circ}-10^{4}$ year time scales. Part 2: Sensitivity experiments with a seasonal, hemispherically averaged, coupled atmosphere, land, and ocean energy balance model. $J$. Geophys. Res., 90, 2207-2222.

Hoffert, M.I. and B.P. Flannery, 1985: Model projections of the time-dependent response to increasing carbon dioxide. In: Projecting the climatic effects of increasing carbon dioxide. Report D.O.E./ER-0237. U.S. Department of Energy, Washington, D.C., 151190.

Hoshiai, M., 1984: In: Unusual Weather Report' 84, Japan Meteorological Agency, 17pp (in Japanese).

Jones, P.D., S.C.B. Raper, R.S. Bradley, H.F. Diaz, P.M. Kelly and T.M.L. Wigley, 1986a: Northern hemisphere surface air temperature variation: 18511984. J. Climate Appl. Meteor., 25, 161-179.

Jones, P.D., S.C.B. Raper and T.M.L. Wigley, 1986b: Southern Hemisphere surface air temperature variation: 1851-1984. J. Climate Appl. Meteor., 25, 1213-1230.

Jones, P.D., S.C.B. Raper and P.M. Kelly, 1988: Causes. of interannual global temperature variations over the period since 1861. In H. Wanner and U. Siegenthaler (eds.): Long and short term variability of climate. Lecture notes in earth sciences, 16 Springer-Verlag, Berlin, 18-34.

Lamb, H.H., 1970: Volcanic dust in the atmosphere; with a chronology and assessment of its meteoro- 
logical significance. Phil. Trans. Roy. Soc. London, 266A, 425-533.

Lin, C.A., and J.N. Koshyk, 1987: A nonlinear stochastic low-order energy balance climate model. Climate Dynamics, 2, 101-116.

Loginov, B.F., 1984: Volcanic Eruption and Climate. Gidrometeoizdat, 64pp (in Russian).

Machta, L. and K. Telegadas, 1974: Inadvertent largescale weather modification. In W.N. Hess (ed.): Weather and Climate Modification. John Wiley and Sons, New York, 687-725.

Madden, R.A. and V. Ramanathan, 1980: Detecting climatic change due to increasing carbon dioxide. Science, 209, 763-768.

Miles, M.K. and P.B. Gildersleeves, 1978: A statistical study of the likely influence of some causative factors on the temperature change since 1665. Meteor. Magazine, 107, 193-204.

Mitchell, J.M., 1970: A preliminary evaluation of atmospheric pollution as a cause of the global temperature fluctuation of the past century. In S.F. Singer (ed.): Global effects of environmental pollution. D. Reidel Publ. Co., Dordrecht, 139-155.

Mitchell, J.M., 1982: El Chichon, Weather-maker of the century? Weatherwise, 35, 252-262.
Newhall, C.G. and S. Self, 1982: The volcanic explosivity index (VEI): An estimate of explosive magnitude for historical volcanism. J. Geophys. Res., 87, 12311238.

Nicolis, C., 1988: Transient climatic response to increasing $\mathrm{CO}_{2}$ concentration: some dynamical scenarios. Tellus. 40A, 50-60.

Nicolis, C., and G. Nicolis, 1979: Environmental fluctuation effects on the global energy balance. Nature, 281, 132-134.

Robock, A., 1978: Internally and Externally caused climate change. J. Atmos. Sci., 35, 1111-1122.

Sellers, W.D., 1969: A global climatic model based on the energy balance of the earth-atmosphere system. J. Appl. Meteor., 8, 392-400.

Simkin, T., L. Siebert, L. McClelland, D. Bridge, C.G. Newhall and J.H. Latter, 1981: Volcanoes of the World, Hutchinson Ross, Stroudsberg, Penn., 233pp.

Willson, R.C. and H.S. Hudson, 1988: solar luminosity variations in solar cycle 21 . Nature, 332, 810-812.

Yamamoto, R. and M. Hoshiai, 1980: Fluctuations of the Northern Hemisphere mean surface air temperature during recent 100 years, estimated by optimum interpolation. J. Meteor. Soc. Japan, 58, 187-193.

\section{最近の気候変動における内因と外因 ーエネルギー平衡気候モデルによる数值実験一 畑澤宏善1・岩嶋樹也 \\ (京都大学理学部附属気候変動実験施設)}

1 年から 100 年程度の時間スケールの気候変動につらて、その内因と外因とを考えた。内因は地球気候 系内の非線形相互作用等によるものであり、とれを時間スケールの短い変動による stochastic forcing とし て扱い、外因としては主に大気中の $\mathrm{CO}_{2}$ 濃度の増加と火山活動とをとりあげた。簡単なエネルギー平衡気 候モデルを用いて最近 100 年間の全（半）球平均気温に関するシミュレーション的数值実験を行い、上記 要因の気候変動における役割について次のような結果を得た:

(1) $\mathrm{CO}_{2}$ 濃度增大の効果は 10 年以上の長い時間スケールで重要である。約 $80 \%$ 以上の信頼限界で考えた 場合、これまでに $\mathrm{CO}_{2}$ 濃度の増大による昇温があったかどらかを結論するてとは現時点ではできないが、 もしも今後大きな火山噴火がなければ 2020 年頃までには有意な昇温を検出できるものと考えられる。

(2) これまでの間久的な火山活動は、特に 10 年程度以下の時間スケールの北半球における気温変動に影 響があったと考えられる。

(3) 北半球の直達日射量の変動は気温の変動によく対応している。この変動は主に火山活動によるもの と推定されるが、近年においては産業活動等による aerosol の影響も含まれていると考えられる。

(4) 最近 100 年間における気温変動の分散には、Nicolis (1988) が主張するよらな単調な増大はみられず、 むしろある幅の中で推移しており、従って multiplicative stochastic forcingによるものとは考えられない。 てれを additive stochastic forcing によるものと考元た場合、その大きさは入射する太陽放射の $0.22-0.28$ \%程度で、その主要因は地球気候系内にあると考元られる。

てのよらな結果から、最近 100 年間の気候変動は、 $\mathrm{CO}_{2}$ 濃度の増加による長期的な昇温を背景として、 
これに火山活動による 10 年スケールの変動と地球気候系内に起因する additive stochastic forcing による 年々の変動が加わっているものと推論される。

\footnotetext{
1現所属：(株) 富士通ソーシアルサイエンスラボラトリ
} 